\title{
Slow mass movement in the Kangchenjunga Area, Eastern Nepal Himalaya
}

\author{
Dhananjay Regmi* and Teiji Watanabe \\ Graduate School of Environmental Earth Science, Hokkai do University, Sapporo 060-0810, JAPAN \\ * To whom correspondence should be addressed. E-mail: regumi @ees.hokudai.ac.jp
}

Solifluction collectively represents slow mass wasting processes associated with freeze thaw action (Ballantyneand Harris 1994, French 1996). Solifluction operates slowly, in general, at a rateof at most $1 \mathrm{~m}_{\text {year }}{ }^{-1}$. Solifluction, nevertheless, contributes greatly to the evolution of mountain landscapes because of its widespread coverage on mountain slopes. Besidelargecoverage of periglacial environment, no efforts haveyet been madein the cold region of the Nepal Himalaya, which ischaracterized by high relief, steep slope, and concentrated monsoon precipitation. This studyattempts to quantify therateand depth of displacementof the solifluction lobe in the uppermost part of the Ghunsa valley in the Kangchenjunga area (Figure1).

Theaccumulated displacement was measured using nonelectric probe, i.e., glass fiber tubes at sites A and B (Figure 1) from 7 November 1998to 26November 2001. Soil auger, 1-m long and $13 \mathrm{~mm}$ in diameter was used to make a hole in the ground. Thefiber tubein onesidewastied with a small nut-boltto prevent from uplifting by frostheaving. Thesidewith nut-bolt wasplaced downward and inserted inside the ground with the help of steel pipe. The remaining gap was filled with fine soil. To obtain the displacement rate, theground was excavated after two yearsand carefully scratched from oneside of thefiber tubeleaving another sidesticking with theground.

An improved strain probemethod (Yamada and Kurashige 1996) was used to monitor continuous soil displacement from 1 December 2001 to 21 September 2002 at siteB. An automatic data logger (KADEC-U of KONA System Co.), which stores data at intervals of one hour, was connected to the strain probe.

In addition, ground temperatures and soil moisture were monitored in order to understand the solifluction process. Ground temperatures of the solifluction lobes were monitored at three different depths of 6,12 and $18 \mathrm{~cm}$ using data loggers (Thermo Recorder TR-52 of T \& D Co.) from 24 April 2001 to 21 September 2002. Furthermore, the year-round ground temperature data taken on the mid-slope at $5433 \mathrm{~m}$ in altitude were used to show the general ground thermal condition. The soil moisture was measured only for 22 days from 19 April to 11 May, 2002. Soil moisturewas measured by a soil moisturesensor (Theta Probe Type ML2x of Delta -T Devices Ltd) with $\pm 1 \%$ accuracy. Rain gauge wasinstalled on themid-slopeat $5235 \mathrm{~m}$ in altitude from 21 April to 22 September, 2002 (Figure 1). Precipitation data were recorded in a logger (HOBO Event of
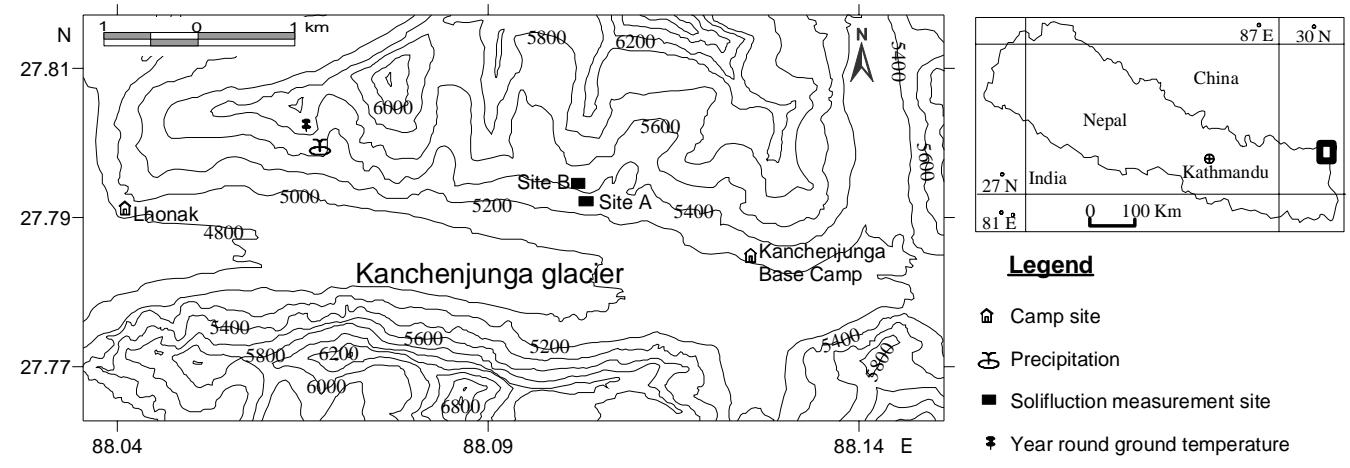

FIGURE 1. Location of the study area

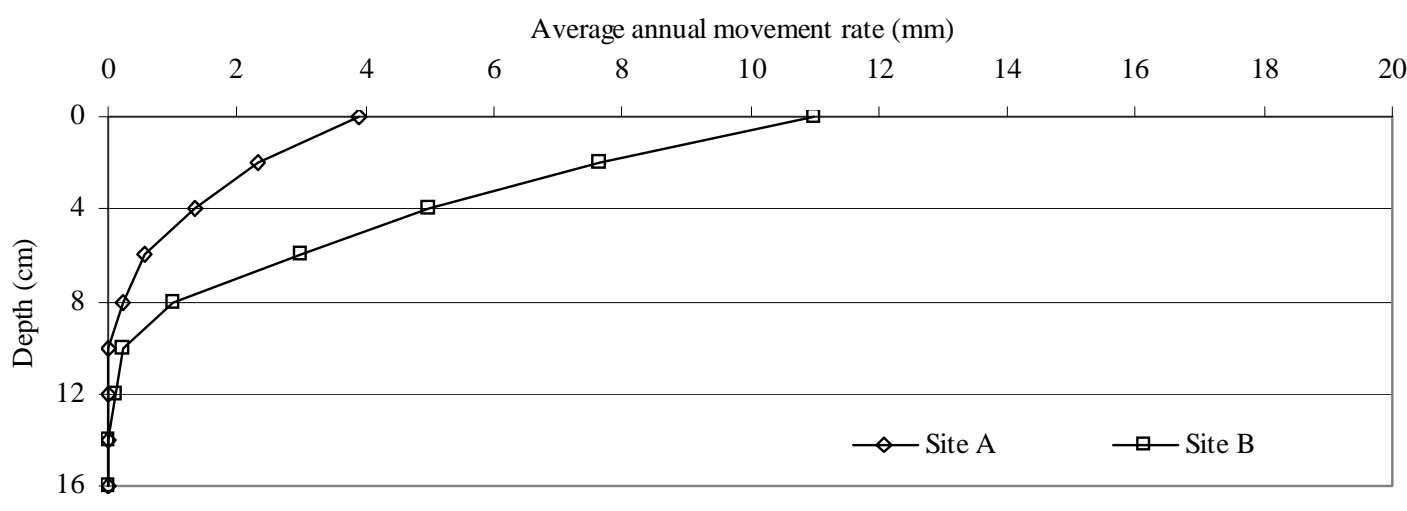

FIGURE 2. Average annual accumulated displacement rate of solifluction lobe at sites $A$ and $B$ 


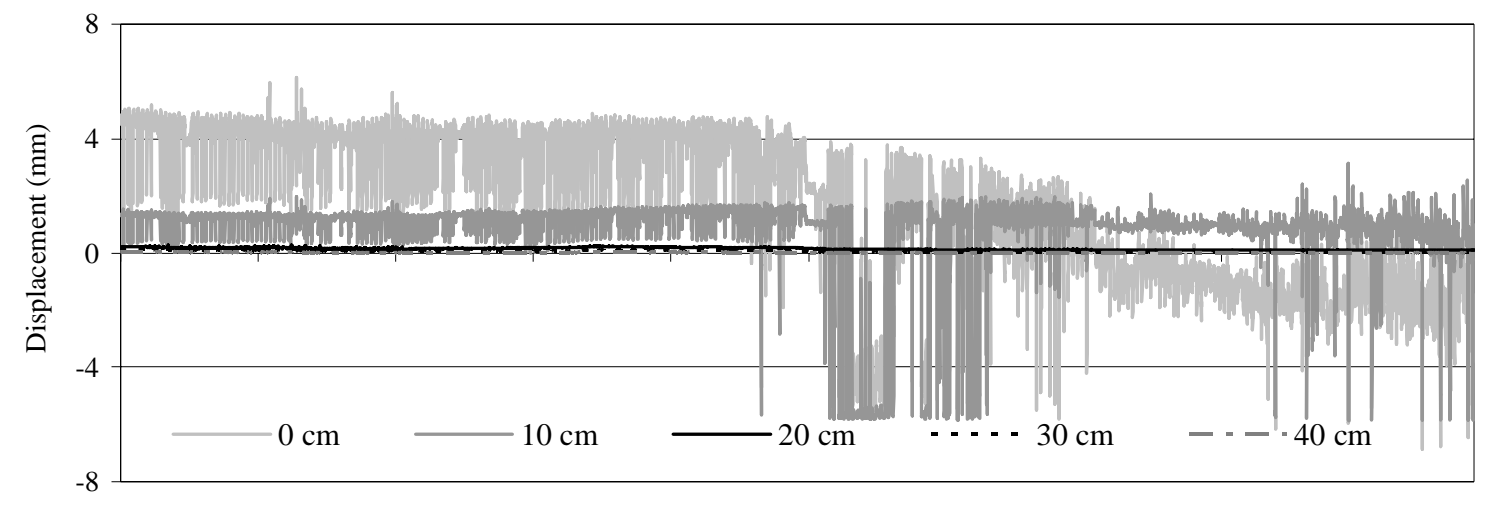

FIGURE 3. Displacement of soil at $0 \mathrm{~cm}, 10 \mathrm{~cm}, 20 \mathrm{~cm}, 30 \mathrm{~cm}$ and $40 \mathrm{~cm}$ depth from 1 December 2001 to 21 September 2002 at 5408 m (site B)

Onset Computer Co.) connected to a standard tipping-bucket rain collector.

Theaverage movement rate of the glass fiber tubes at 5412 - $5414 \mathrm{~m}$ altitude with slope angle of $31^{\circ}$ was about $11 \mathrm{~mm} /$ year, which was almost threetimeslarger than that observed at 5322 $5325 \mathrm{~m}$ with $22^{\circ}$ slope angle (Figure 2). There was no significant differencein the depths which caused displacement at both sites. The continuous displacement near the ground surface at 5414 $\mathrm{m}$ shows permanent downslope movement from the middle of June. It may beattributed to high moisturesupply in soil derived from precipitation. Theamplitude of the displacement cyclewas the largest at the ground surface, decreasing with increasing depth: the amplitude at and below $20 \mathrm{~cm}$ in depth is virtually zero (Figure 3). Although the soil moisture rises at each depth after precipitation events, thesoil moisture content in general is very low. The low moisture content and the absence of freezethaw during monsoon period may be major factors leading to theslow rate of downslope displacement in this area.

\section{References}

Ballantyne CK and C Harris. 1994. The Periglaciation of Great Britain. Cambridge University Press, Cambridge. $325 \mathrm{p}$

French HM. 1996. The Periglacial Environment, $2^{\text {nd }}$ ed. Longman, Essex. $309 p$

Yamada Sand Y Kurashige. 1996. Improvement of strain probe method for soil creep measurement. Transactions Japanese Geomorphological Union 17: 29-38 